\title{
Teaching NeuroImages: Central Serous Chorioretinopathy After Corticosteroid Treatment for Optic Neuritis
}

Jennifer Ling, MSc, and Jonathan A. Micieli, MD, CM

Neurology ${ }^{\circledR}$ 2021;96:e305-e306. doi:10.1212/WNL.0000000000010807

Figure Superior Central Serous Chorioretinopathy (CSCR) in the Right Eye and Central CSCR in the Left Eye After Corticosteroid Treatment for Optic Neuritis

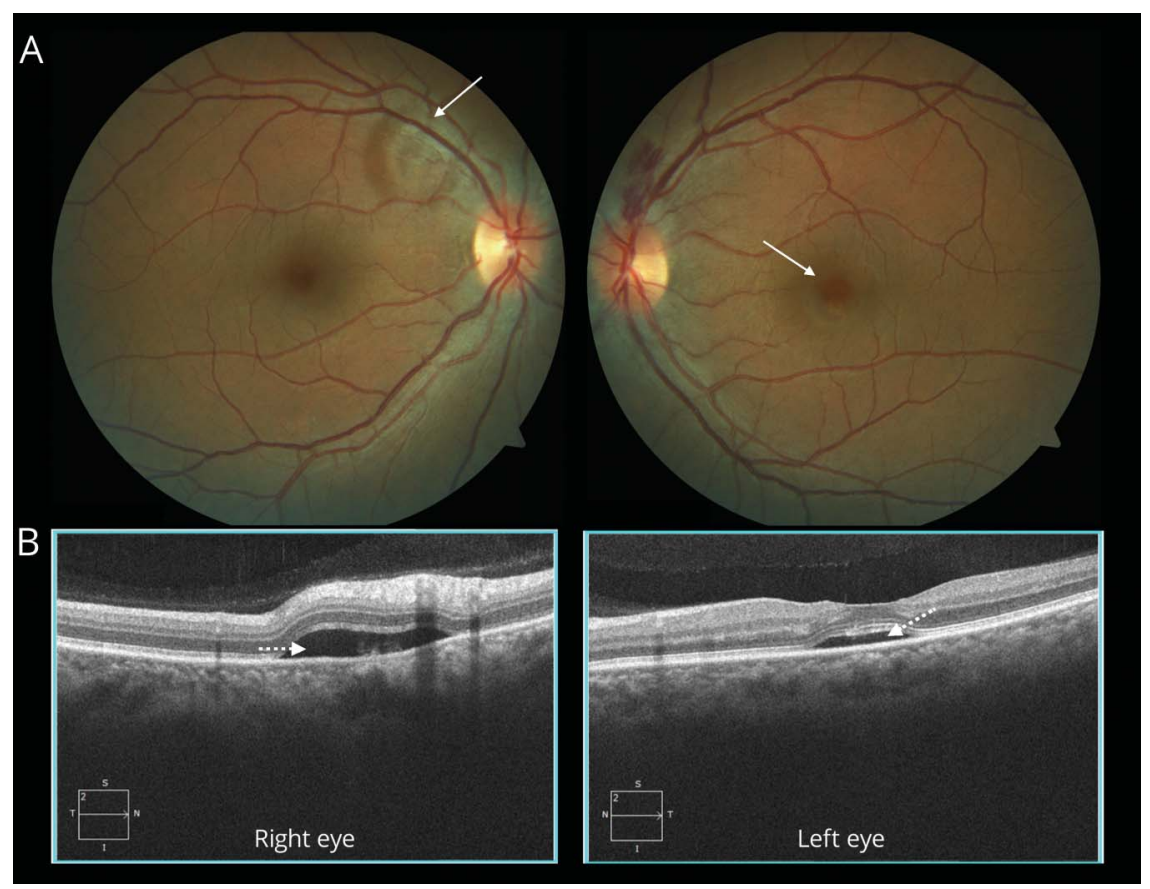

(A) Color fundus photographs demonstrating a localized superior serous detachment of the retina in the right eye (white arrow) and subfoveal serous detachment of the retina in the left eye (white arrow). (B) Optical coherence tomography of the macula over the localized areas of serous retina detachments demonstrating the subretinal fluid in both eyes (dashed white arrow).

A 37-year-old woman presented with a 1-week history of painful vision loss in both eyes from optic neuritis. She was treated with intravenous, followed by oral corticosteroids. After she completed intravenous corticosteroids, she developed a new area of blurred vision inferiorly (right eye) and centrally (left eye) secondary to central serous chorioretinopathy (CSCR), which resolved after oral prednisone taper (figure). CSCR is characterized by well-circumscribed serous detachments of the retina and is typically seen after exogenous corticosteroid use. CSCR can be misdiagnosed as optic neuritis ${ }^{1}$ or develop in patients with optic neuritis after corticosteroid treatment ${ }^{2}$ and should be kept in the differential diagnosis for worsening vision after corticosteroids.

\section{Correspondence}

Dr. Micieli

jmicieli@

kensingtonhealth.org

\section{MORE ONLINE}

$\rightarrow$ Teaching slides

links.lww.com/WNL/

B213

From the Faculty of Medicine (J.L.), University of British Columbia, Vancouver, British Columbia, Canada; Department of Ophthalmology and Vision Sciences (.A.M.), University of Toronto, Toronto, Ontario, Canada; Division of Neurology (J.A.M.), Department of Medicine, University of Toronto, Toronto, Ontario, Canada; and Kensington Vision and Research Centre (J.A.M.), Toronto, Ontario, Canada.

Go to Neurology.org/N for full disclosures. Funding information and disclosures deemed relevant by the authors, if any, are provided at the end of the article. 


\section{Study Funding}

No targeted funding reported.

\section{Disclosure}

The authors report no disclosures relevant to the manuscript. Go to Neurology.org/N for full disclosures.

\section{Appendix Authors}

\begin{tabular}{lll}
\hline Name & Location & Contribution \\
\hline Jennifer Ling & $\begin{array}{l}\text { University of } \\
\text { British } \\
\text { Columbia }\end{array}$ & $\begin{array}{l}\text { Design and conceptualized the study, } \\
\text { analyzed the data, and drafted the } \\
\text { manuscript for intellectual content }\end{array}$ \\
\hline
\end{tabular}

Appendix (continued)

\begin{tabular}{|c|c|c|}
\hline Name & Location & Contribution \\
\hline $\begin{array}{l}\text { Jonathan } \\
\text { Micieli, MD, } \\
\text { CM }\end{array}$ & $\begin{array}{l}\text { University of } \\
\text { Toronto }\end{array}$ & $\begin{array}{l}\text { Design and conceptualized } \\
\text { the study, analyzed } \\
\text { the data, and critical } \\
\text { revision of the } \\
\text { manuscript }\end{array}$ \\
\hline
\end{tabular}

\section{References}

1. Bialer OY, Newman NJ, Bruce BB, Biousse V. "Optic neuritis" that is neither. Neurol Clin Pract 2013;3:168-170.

2. Raimundo M, Fonseca C, Lemos J, Fonseca P. Central serous chorioretinopathy as a cause of vision loss in chronic relapsing inflammatory optic neuropathy. Am J Ophthalmol Case Rep 2018;11:131-134. 


\section{Neurology}

\section{Teaching NeuroImages: Central Serous Chorioretinopathy After Corticosteroid Treatment for Optic Neuritis \\ Jennifer Ling and Jonathan A. Micieli}

Neurology 2021;96;e305-e306 Published Online before print September 11, 2020

DOI 10.1212/WNL.0000000000010807

This information is current as of September 11, 2020

\section{Updated Information \&} Services

\section{References}

Subspecialty Collections

Permissions \& Licensing

Reprints including high resolution figures, can be found at: http://n.neurology.org/content/96/2/e305.full

This article cites 2 articles, 1 of which you can access for free at: http://n.neurology.org/content/96/2/e305.full\#ref-list-1

This article, along with others on similar topics, appears in the following collection(s):

Optic neuritis; see Neuro-ophthalmology/Optic Nerve

http://n.neurology.org/cgi/collection/optic_neuritis

\section{Retina}

http://n.neurology.org/cgi/collection/retina

Information about reproducing this article in parts (figures,tables) or in its entirety can be found online at:

http://www.neurology.org/about/about_the_journal\#permissions

Information about ordering reprints can be found online:

http://n.neurology.org/subscribers/advertise

Neurology ${ }^{\circledR}$ is the official journal of the American Academy of Neurology. Published continuously since 1951 , it is now a weekly with 48 issues per year. Copyright @ 2020 American Academy of Neurology. All rights reserved. Print ISSN: 0028-3878. Online ISSN: 1526-632X.

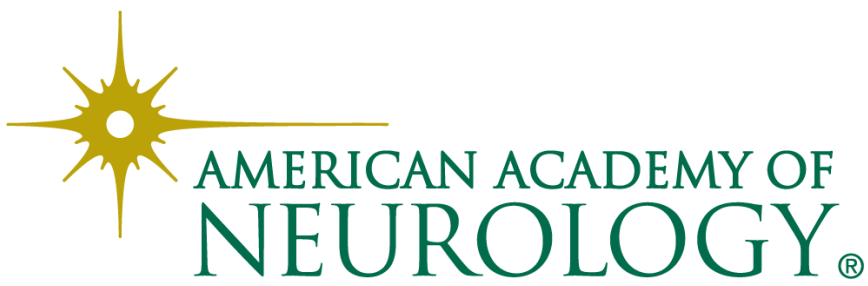

